\title{
Gender Discrimination at Job Application Process: An Experimental Study at Hotels
}

\author{
Rahman TEMIZKAN iD a Yasin Emre OĞUZ iD b Beybala TIMUR iD c \\ a Travel Management and Tour Guiding, Eskisehir Osmangazi University, Eskişehir, Turkey. rahmantemizkan@hotmail.com \\ b Tourism Management, Eskisehir Osmangazi University, Eskişehir, Turkey. yeoguz@gmail.com \\ c Travel Management and Tour Guiding, Eskisehir Osmangazi University, Eskişehir, Turkey. beybalatimur@gmail.com
}

\begin{tabular}{|c|c|}
\hline ARTICLE INFO & ABSTRACT \\
\hline Keywords: & Purpose - This study aims to examine gender discrimination during the employee hiring process in \\
\hline Employment & the hotel industry which is considered as the largest subsector of the tourism industry. \\
\hline Human Resource & Design/methodology/approach - The population of the study consists of a total of $273-, 4-$, and 5- \\
\hline Management & star hotels located in Eskisehir. The study utilized an experimental method to collect data from 23 \\
\hline Gender Discrimination & hotels. \\
\hline Eskisehir & Findings - Findings indicate no sign of gender discrimination at 4-star and 5-star hotels' job \\
\hline $\begin{array}{l}\text { Received } 29 \text { November } 2019 \\
\text { Revised } 5 \text { April } 2020\end{array}$ & $\begin{array}{l}\text { application interview process. However, evidence of gender discrimination was found at } 57 \% \text { of } 3- \\
\text { star hotels' job applications. }\end{array}$ \\
\hline Accepted 4 May 2020 & $\begin{array}{l}\text { Discussion - Hotels in Eskisehir do not discriminate applications on purpose. However, some hotels } \\
\text { discriminate applicants unintentionally. This mostly occurs due to managers' lack of broader }\end{array}$ \\
\hline Article Classification: & knowledge about the discrimination concept. \\
\hline
\end{tabular}

Research Article

\section{INTRODUCTION}

It is a well-known fact that tourism is labor-intensive (Unluonen, Tayfun, and Kiliclar, 2015) and frontline employees who directly interact with customers are an important aspect of touristic products (Tukelturk, Percin, and Guzel, 2014). Thus, human resource management strategies and managers play a critical role in the recruitment processes (Pelit, 2015). The main functions of human resources management are listed as work analysis, human resources planning, finding, choosing and hiring employee, education and development, performance evaluation, career planning and management, work evaluation and determining salary, employee health, and security (Mathis and Jackson, 2000).

This study is based on the hiring process which is considered one of the most important aspects of human resources management. HR managers have to consider ethical and legal issues as much as finding and hiring the right employee for the job. Observing the legal legislations during the employee hiring process will prevent the companies from facing civil conspiracies and damaging the image of the company (Mathis and Jackson, 2000). Discrimination is a human rights violation as it is illegal when it is done deliberately or not during the hiring process (Temizkan, 2010). The most common discrimination type that occurs during the hiring process is gender discrimination (Demir, 2011). Thus, this study aims to examine gender discrimination during the employee hiring processes in the hotel industry which are considered as the largest subsector of the tourism industry.

The results of studies that have focused on discrimination (Örücü, 2002; Benli and Sahin, 2004; Akova, Sariisik and Akbaba, 2007; Skalpe, 2007; Thrane, 2008; Akbaba and Gunlu, 2011; Keskin and Yazici, 2016; Aslan and Dincer, 2017; Costa, Bakas, Breda, Durao, Carvalho and Cacador, 2017; Schum, Gatling and Garlington, 2019) are considered debatable in terms of reliability. Because these studies utilized survey forms or interviews during data collection. While employers claim that they do not discriminate, applicants claim that they are a victim of discrimination. Both sides mount tangible or intangible arguments to prove their claims. From this point of view, the researchers thought that a different method should be utilized to measure discrimination.

\section{Önerilen Atıf/Suggested Citation}

Temizkan, R., Oğuz, Y. E., Timur, B. (2020). Gender Discrimination at Job Application Process: An Experimental Study at Hotels, Journal of Business Research-Turk, 12 (2), 1121-1129. 
Thus, the researchers used an experimental method to determine if the hotels in Eskişehir discriminate applicants. This is considered as the originality of the study.

The study aims to determine if the 3-, 4-, and 5-star hotels discriminate applicants according to their genders during their hiring processes. The employee hiring process plays a critical role in the tourism industry where human resources have a great impact on operations. Negative discriminations during these processes may cause damage to the company's image and companies may have to pay compensations due to legal fines. Creating awareness about this issue in Eskisehir is important for tourism businesses.

\section{CONCEPTUAL FRAMEWORK}

This part defines employee finding, selection processes, and discrimination concepts. An employee is a person who works in the workplace. The word employee is synonymous with staff, personnel, and worker. And employee finding and hiring processes are considered as the most important stage of the human resources planning process (Sabuncuoglu, 2016). The employee finding process involves attracting the candidates with adequate skills and knowledge for the job (Yuksel, 2007). In other words, employee finding is making a qualified workforce to apply for vacant positions (Cavdar and Cavdar, 2010). Hiring the right employee for work plays a critical role since it will affect work efficiency (Örücü, 2002).

The most important aspect that affects the success of a business in the service industry is the employees. Companies use internal and external resources to supply their workforce need (Ozgen and Yalcin, 2010). Using internal resources means finding an employee who already works in the company for a new position. Using external resources means finding an employee from the outside. Both strategies have advantages and disadvantages (Yuksel, 2007). Using internal resources may motivate the current employees positively, increase employees' loyalty and decrease employee finding costs (Ozgen and Yalcin, 2010; Pelit, 2015). However, it would raise doubt about nepotism among other employees, also it may prevent new ideas and fresh blood from coming into the business. Using external resources helps to bring new ideas in, provides more employee choices, clears the doubts on nepotism and prevents conflicts between employees (Findikci, 1999). But it has downsides too. Using external resources would affect the current employees' motivation negatively. New employees' education and adaptation periods may take a while (Sabuncuoglu, 2016). There are several methods to receive applications through internal resources and external resources. In the case of internal resources, an employee is found through promotion, internal transfer, skill inventory, and interorganizational open position notice. However, in the case of an external resource, applications are received through a public open position announcement, advertisement, application in person, unions, suggestions, human resources businesses, internet applications (Ozgen and Yalcin, 2010).

The employee hiring process is defined as choosing the most adequate person among several applicants for the open or future positions to keep the business running (Sabuncuoglu, 2016). This process involves several stages starting with receiving the applications and ending with the decision to hire (Ozgen and Yalcin, 2010). The basic foundation of the employee hiring process is work analysis and human resources planning which should be done before the hiring process. The most common employee hiring methods are interviews, exams, achievement tests, and motivation tests (Yuksel, 2007). Human resources managers should consider some important principles during the hiring process. These are: (Dessler, 2002):

- Employee hiring should be done by the "man for work" principle.

- Candidates' skills and qualifications should be evaluated correctly.

- The human resources department should keep all the records in their archives.

- Candidates who seem unable to adapt to the organizational culture or have inappropriate attitudes should be eliminated.

- Candidate references should be checked.

- The hiring committee should avoid any kind of discrimination.

These principles highlight one of the variables of this study which is discrimination. Ataov (1996) defines discrimination as depriving one or more member/s of a state or community of specific rights or privileges. 
Primary elements of discrimination are gender, race, color, language, religion, marital status and political views (Demir, 2011).

The literature review points out that the results of studies on discrimination in the tourism sector do not show a significant difference due to their methodologies. Studies mostly utilize surveys (Örücü, 2002; Akova, Sariisik and Akbaba, 2007; Akbaba and Gunlu, 2011; Costa, Bakas, Breda, Durao, Carvalho and Cacador, 2017; Schum, Gatling, and Garlington, 2019), interpreting secondary data (Skalpe, 2007; Thrane, 2008) and interviews Benli and Sahin, 2004; Keskin and Yazici, 2016; Aslan and Dincer, 2017).

Human resources planning plays a critical role especially for touristic businesses in terms of finding the right employee (Benli and Sahin, 2004). However, recently employee hiring resources do not differ according to the industries and businesses do not adopt a strategical management approach during the hiring processes (Akbaba ve Gunlu, 2011; Keskin and Yazici, 2016). Human resource managers mostly use online resources during hiring processes (Akova, Sariisik, and Akbaba, 2007). However, businesses' expectations from employees differ according to the positions. While education and experience criteria are prominent for midlevel and top executive managers (Örücü, 2002), appearance and personality characteristics criteria are prominent for lower positions (Akova, Sariisik, and Akbaba, 2007).

One of the most common problems faced during the hiring process in the tourism industry is discrimination. In some cases, discrimination becomes inevitable. This situation is guaranteed by the Constitution of the Republic of Turkey. According to the 50th article of the constitution, people can not be forced to work that is not suitable for their gender, age or strength (Bingöl, 2010). However, this study addresses discrimination by tolerating an individual or a group more than other members of the community. In this context, it is a known fact that application forms in the tourism industry have discriminating aspects. Moreover, some human resource managers think that these aspects are "must-be" in application forms (Yesiltas, Temizkan, Temizkan and Arslan, 2013). The most common discrimination type in the tourism sector is determined as gender discrimination (Aslan and Dincer, 2017). Announcing that a man or a woman will be hired for a job is considered as gender discrimination unless there is a legal necessity or the nature of the job requires so (Bingol, 2010).

If the case was the life expectation or choice differences between men and women, separating genders would not be perceived as discrimination. But when separation causes monetary and tangible losses and inequality of opportunity, it becomes an issue to be resolved (Bora, 2012). Thus, this study aims to determine if the hotels in Eskisehir discriminate applicants during the hiring process. Also in business life, discrimination is mostly perceived in favor of men. However, this study aims to determine discrimination regardless of gender.

\section{METHODOLOGY}

The research designs are chosen to answer the question in hand rather than a personal choice. If the case is about observing behaviors or determining perceptions survey forms might be a useful tool. However, if the researchers are looking for a cause relationship, an experimental approach would be more suitable. Because adopting the most suitable research design and its implementation is the main factor to reach valid and reliable conclusions. It is a well-known fact that well-designed experiments can achieve much more efficient results than other research designs since it explains cause and effect relationships. Consequently, the results will provide more reliable and tangible practical solutions and recommendations (Viglia and Dolnicar, 2020). Thus, this study adopts the experimental method because the experimental method is considered as the purest in terms of the positivist approach standards. It provides comprehensive information since it is result-oriented. However, it has weaknesses as much as any other methodology does (Neuman, 2017:358). The main reason to adopt this method is that, as mentioned before, it provides more reliable results (Buyukozturk, Cakmak, Akgun, Karadeniz and Demirel, 2008).

An experimental method is a strong tool to focus on causal relationships. It follows the rules of positivist science strictly. The experimental method is considered as the best approach for subjects with a narrow width in general. It allows the researchers to conduct many experiments with limited resources in a short time. They also help the researchers to isolate the effects of one or more causal variables (Neuman, 2017: 359). The researchers who use the experimental method, in general, measure the dependent variable more than once. They conduct a preliminary test where they do not manipulate anything. Then they conduct a posttest where 
they measure the dependent variable by manipulating the experimental situation. To do this, the intervention must be done by the researchers at the right stage. This means the intervention must be made before the outcome. Otherwise, the outcome might be the same (Viglia and Dolnicar, 2020). The researchers mostly separate subjects into two groups which are named the experimental group and control group. The experimental group is the group that the researchers manipulate. The control group is the group that the researchers do not manipulate (Neuman, 2017: 367).

There are different experimental study designs for different studies like laboratory experiments, field experiments, choice experiments, natural and quasi-experiments. The researchers first planned to use a natural experiment method which is defined as where the treatment occurs unplanned for this study. However, in this case, the study design is more suitable for the quasi-experimental design which is used when the natural design is inconvenient to measure the causal relationships. Thus, a quasi-experimental method where the treatment is planned by the researchers intentionally before the implementation (Viglia and Dolnicar, 2020) was chosen. The quasi-experimental method has different approaches. The factorial design which is one of the quasi-experimental methods is used to measure the simultaneous effects of two independent variables in this study. In factorial design cases, manipulation is the combination of the categories rather than each independent variable (Neuman, 2017: 371-375). Bardack and McAndrew (1985) used a factorial design to determine the effect of physical attraction and proper dressing on hiring decisions and determined that both variables have effects on hiring decisions separately and in combination.

\section{Quasi-experimental Method in Tourism Studies}

Several studies adopted the quasi-experimental method in different cases in tourism literature. Arana and Leon (2008) focused on the effect of terrorism demand and stated that terrorist attacks may change the image of destinations on tourists' minds. Chen et. al. (2013) investigated tourists' subjective well-being and found that while their chronic subjective well-being does not change their occasion-specific subjective well-being increases right after the vacation and lasts for two months. Pabel and Pearce (2016) aimed to determine the tourists' responses to humor during the tour guides' presentation. They found that manipulation during the quasi-experiment did not enhance the desired level of amusement however tourists were fairly happy with the level of humor. Dolnicar et al. (2018) tested the relationship between pro-environmental appeals and proenvironmental behavior in hotels. They stated that pro-environmental appeals do not trigger the tourists' proenvironmental behaviors. Zavattaro and Fay (2019) investigated the success of national tourism marketing strategies named as Brand USA. Their results indicate that Brand USA's marketing efforts have some weaknesses in the context of place marketing.

However, these quasi-experimental studies focused on different areas of tourism rather than gender discrimination. Thus, this study uses a quasi-experimental design to determine the effect of gender on hiring decisions. This also constitutes the originality of the study.

\subsection{Research Universe and Sampling Method}

The research universe consists of a total of 27 hotels with 3, 4 and 5 stars. A sampling method is chosen because time and cost restraints and the possibility of some of the hotel managers would not be willing to participate in the study. Thus, hotel information is gathered from Eskisehir State Culture and Tourism Department. 
R. Temizkan - Y. E. Oğuz - B. Timur 12/2 (2020) 1121-1129

Table 1. 3, 4 and 5 Star Hotels in Eskisehir

\begin{tabular}{|c|c|c|c|}
\hline Hotel Name & Stars & Number Of Rooms & Number Of Beds \\
\hline Eskişehir Anemon Hotel & 5 star & 174 & 348 \\
\hline Park Dedeman Eskisehir & 5 star & 129 & 257 \\
\hline Tasigo Hotel \& Resort & 5 star & 164 & 328 \\
\hline Capella Otel & 4 star & 125 & 250 \\
\hline Divan Express Eskisehir & 4 star & 105 & 210 \\
\hline Hilton Garden Inn & 4 star & 126 & 252 \\
\hline Modernity & 4 star & 109 & 225 \\
\hline The Merlot Hotel & 4 star & 80 & 160 \\
\hline Ada Life Otel & 3 star & 31 & 52 \\
\hline Arus Hotel & 3 star & 66 & 132 \\
\hline Atışkan Otel & 3 star & 62 & 124 \\
\hline Dedepark Otel & 3 star & 65 & 130 \\
\hline Enotel Karaca & 3 star & 40 & 80 \\
\hline Es Albatros Otel & 3 star & 82 & 164 \\
\hline Eskişehir İbis Otel & 3 star & 108 & 216 \\
\hline Grand Şah Otel & 3 star & 41 & 61 \\
\hline Hangover Central Hotel & 3 star & 57 & 114 \\
\hline Ramada Encore Hotel & 3 star & 61 & 122 \\
\hline Roof Garden Hotel & 3 star & 57 & 114 \\
\hline Sarar Otel & 3 star & 65 & 130 \\
\hline Sennacity Otel & 3 star & 47 & 94 \\
\hline Soyiç Otel & 3 star & 62 & 124 \\
\hline Sör Otel & 3 star & 48 & 96 \\
\hline Tymbris Otel & 3 star & 48 & 91 \\
\hline Uysal Termal Otel & 3 star & 35 & 70 \\
\hline Vendome Hotel & 3 star & 19 & 38 \\
\hline Verman Otel & 3 star & 49 & 98 \\
\hline
\end{tabular}

Table 1 shows that there are (3) 5-star hotels, (5) 4-star and (19) 3-star hotels in Eskisehir. In this context, subjects applied for jobs at (3) 5-star hotels, (5) 4-star, and (14) 3-star hotels. (5) 3-star hotels were excluded because the researchers could not reach out to the managers.

\subsection{Data Collection}

The researchers decide the number of groups, manipulation conditions, how many times they will measure the independent variable, what subjects will exactly do during the experiment. After deciding these, the researchers assign the subjects randomly to the groups and start the experiment. Subjects are given strict orders about how to act. First, the researchers measure the dependent variable with a pretest. Then the researchers manipulate the experiment group. Finally, they measure the dependent variable again with the posttest and determine if the results support the suggested hypothesis (Neuman, 2017: 367). Thus, an experimental group was chosen from 1 male and 1 female volunteer. 
R. Temizkan - Y. E. Oğuz - B. Timur 12/2 (2020) 1121-1129

Table 2. Profiles of the Experimental Group

\begin{tabular}{cc}
\hline 1st Subject & 2nd Subject \\
\hline Female & Male \\
B Level English & B Level English \\
Tourism Graduate & Tourism Graduate \\
22 years old & 22 years old \\
Single & Single \\
Same Level Experience & Same Level Experience \\
Same References & Same References \\
\hline
\end{tabular}

The experimental group profile was determined at the data collection stage (Table 2). Subjects' profiles were designed the same except the gender. According to the scenery generated by the researchers, subjects are fluent in English, graduated from same level tourism school, 22 years old, single, have the same work experience and the same references. Subjects applied for jobs with their fabricated curriculum vitae and reported their experiences during their application. Subjects assigned to apply to the hotels randomly. Thus, some hotels interviewed the female subject first and some interviewed the male subject first. The researchers evaluated the subjects' experiences in the context of the study.

\section{FINDINGS}

This chapter examines the findings of the study.

\subsection{5-star Hotels}

Subjects applied to 3 5-star hotels' front office department in the context of the study. Both subjects reported that they easily reached to the department managers and had a warm welcome. Also, their reports indicate that they had similar experiences and they were not exposed to discrimination.

\subsection{4-star Hotels}

Subjects applied to 54 -star hotels' front office department. Subjects reported that they had a warm welcome during their visit as they did in 5-star hotels. They reported that they were interviewed by shift leader instead of front office manager at 1 hotel. However, since the study aims to determine gender discrimination, this situation was evaluated insignificant. On the other hand, it is fair to say that subjects were not exposed to gender discrimination at 4-star hotels.

\subsection{3-star Hotels}

Subjects applied to 14 3-star hotels' front office departments out of 19. Subjects tried to reach to the hotel managers at different times. However, they were unable to reach a manager to do a job interview. 3-star hotels' discrimination findings are given in Table 3. 
R. Temizkan - Y. E. Oğuz - B. Timur 12/2 (2020) 1121-1129

Table 3. 3-star Hotels' Gender Discrimination Findings

\begin{tabular}{|c|c|c|c|}
\hline Facility & Respondent & 1st Subject (Woman) & 2nd Subject (Man) \\
\hline Hotel 1 & Front Office Manager & Male for Night Shift & Male for Night Shift \\
\hline Hotel 2 & Hotel Manager & Female for Shift A & Female for Shift A \\
\hline Hotel 3 & Front Office Manager & No gender discrimination. & No gender discrimination. \\
\hline Hotel 4 & Front Office Manager & No gender discrimination. & No gender discrimination. \\
\hline Hotel 5 & Front Office Manager & No gender discrimination. & No gender discrimination. \\
\hline Hotel 6 & General Manager & $\begin{array}{l}\text { Seeking for a male } \\
\text { employee. }\end{array}$ & $\begin{array}{l}\text { Seeking for a male } \\
\text { employee. }\end{array}$ \\
\hline Hotel 7 & General Manager & Male for Night Shift & Male for Night Shift \\
\hline Hotel 8 & Hotel Owner & No gender discrimination. & No gender discrimination. \\
\hline Hotel 9 & Hotel Manager & $\begin{array}{l}\text { Seeking for a female } \\
\text { employee. }\end{array}$ & $\begin{array}{l}\text { Seeking for a female } \\
\text { employee. }\end{array}$ \\
\hline Hotel 10 & Front Office Manager & No gender discrimination. & No gender discrimination. \\
\hline Hotel 11 & Hotel Owner & $\begin{array}{l}\text { Seeking for a female } \\
\text { employee. }\end{array}$ & $\begin{array}{l}\text { Seeking for a female } \\
\text { employee. }\end{array}$ \\
\hline Hotel 12 & Hotel Owner & $\begin{array}{l}\text { Seeking for a female } \\
\text { employee. }\end{array}$ & $\begin{array}{l}\text { Seeking for a female } \\
\text { employee. }\end{array}$ \\
\hline Hotel 13 & Front Office Manager & No gender discrimination. & No gender discrimination. \\
\hline Hotel 14 & General Manager & Male for Night Shift & Male for Night Shift \\
\hline
\end{tabular}

Table 3 shows that 6 hotels out of 14 (43\%) do not do gender discrimination. On the other hand, findings indicate that hotels $6,9,11$ and 12 do gender discrimination even though the employees going to do the same work. Hotel 1, 2, 7 and 14 do gender discrimination over shifts. Subjects reported that the managers who ask for men claim that they do not allow women to work at night shifts.

\section{CONCLUSION}

Studies in social sciences generally aim to examine the human behavior and effects of these behaviors. This study aimed to determine gender discrimination at Eskisehir hotels. The tourism industry is a labor-intensive and 24/7 serving industry. Study findings indicate that 3 hotels' requests for man employees for night shift can be considered as good intentions. The night shift is between $00.00-08.00$ hours and working at those times may be hard for woman employees. However, as mentioned before, to announce that employees from only one gender will be hired will be considered as discrimination (Bingol, 2010; Temizkan, 2010; Demir, 2011). Thus, it is possible to say that 3-star hotels in Eskisehir discriminate applicants even if it is unintentional. Another finding of the study is that people think that they are exposed to discrimination since they are still not familiar with the broad meaning of the concept. In other words, employers limit the job adverts to only women or men for the good of their employees and positive discrimination. However, the applicants from other genders feel that they were negatively discriminated against. These results are consistent with the related literature.

Findings do not show evidence of gender discrimination at 4-star and 5-star hotels. This situation is understandable since Eskisehir city is considered as one of the best inhabitable cities in the world, Eskisehir 
R. Temizkan - Y. E. Oğuz - B. Timur 12/2 (2020) 1121-1129

inhabitants are well educated. Also, the institutionalization of businesses prevents human rights abuses like gender discrimination.

A similar situation is also consistent with 3-star hotels in general. However, in small businesses with few departments and few mid-level managers, discrimination is detected since the managers have to attend to more than one responsibility at the same time. Hotel owners who want to interview the applicants themselves discriminate applicants without knowing. This situation proves the importance of professionalization in the tourism industry.

Future studies should focus on similar experimental researches. These studies will contribute to both tourism literature and the tourism industry. A similar experimental study can be applied to travel agencies and restaurants.

\section{REFERENCES}

Akbaba, A. ve Günlü, E. (2011). “Otel İşletmelerinde İşgören Bulma, Seçme ve Eğitim Sürecinin Stratejik İnsan Kaynakları Bakış Açısıyla Değerlendirilmesi: Beş Yıldızlı Otellerde Bir Araştırma", Sosyal Ekonomik Araştırmalar Dergisi, 11(22): 199-228.

Akova, O., Sarışık, M. ve Akbaba, A. (2007). “Seyahat Acentalarında İşgören Bulma ve Seçme Yöntemlerine Yönelik Bir Araştırma", Karamanoğlu Mehmetbey Üniversitesi Sosyal ve Ekonomik Araştırmalar Dergisi, 2: 275-296.

Araña, J. E., \& León, C. J. (2008). “The impact of terrorism on tourism demand.” Annals of Tourism Research, 35(2), 299-315.

Aslan, S. ve Dinçer, M. (2017). "İstanbul'daki Küçük ve Orta Ölçekli Otel İşletmelerinde İşgören Seçimi”, Uluslararası Yönetim Íktisat ve İşletme Dergisi, 13: 342-350.

Ataöv, T. (1996). Çatışmaların Kaynağı Olarak Ayrımcılık, Ankara: Ankara Üniversitesi Siyasal Bilimler Fakültesi İnsan Hakları Merkezi Yayınları.

Bardack, N. R., \& McAndrew, F. T. (1985). "The influence of physical attractiveness and manner of dress on success in a simulated personnel decision." The Journal of Social Psychology, 125(6), 777-778.

Benli, A. ve Şahin, L. (2004). “İnsan Kaynakları Yönetiminde İşgören Bulma ve Seçme: Çınar Hotel Uygulaması", Bilgi Sosyal Bilimler Dergisi, 1(1): 113-124.

Bingöl, D. (2010). İnsan Kaynakları Yönetimi, İstanbul: Beta Yayım Dağıtım.

Bora, A. (2012). Toplumsal Cinsiyete Dayalı Ayrımcılık, K. Çayır ve M. Ayan Ceyhan (Ed.), Ayrımcılık: Çok Boyutlu Yaklaşımlar, (175-189), İstanbul: İstanbul Bilgi Üniversitesi Yayınları.

Büyüköztürk, Ş., Çakmak Kılıç, E., Akgün, Ö. E., Karadeniz, Ş. ve Demirel, F. (2008). Bilimsel Araştırma Yöntemleri, Ankara: Pegem Akademi Yayıncllı.

Chen, Y., Lehto, X. Y., \& Cai, L. (2013). “Vacation and well-being: a study of Chinese tourists.” Annals of Tourism Research, 42, 284-310.

Costa, C., Bakas, F. E., Breda, Z., Durao, M., Carvalho, I., and Cacador, S.(2017). “Gender, flexibility and the ideal tourism worker'. Annals of Tourism Research, 64,64-75.

Çavdar, H. ve Çavdar, M. (2010). “İşletmelerde İşgören Bulma ve Seçme Aşamaları”, Journal of Naval Science and Engineering, 6(1): 79-93.

Demir, M. (2011). “İş Yaşamında Ayrımcılık: Turizm Sektörü Örneği”, Uluslararası İnsan Bilimleri Dergisi, 8(1): 760-784.

Dolnicar, S., Knezevic Cvelbar, L., \& Grün, B. (2018). “Changing service settings for the environment: How to reduce negative environmental impacts without sacrificing tourist satisfaction." Annals of Tourism Research, 76(C), 301-304.

Fındıkçı, İ. (1999). İnsan Kaynakları Yönetimi, Alfa/Aktüel Kitabevileri. 
R. Temizkan - Y. E. Oğuz - B. Timur 12/2 (2020) 1121-1129

Keskin, Ö. ve Yazıcı, U. (2016). “İşgören Seçiminde Kullanılan Kaynaklar Üzerine Bir Araştırma: Bartın Örneği", Yönetim, Ekonomi, Edebiyat, İslami ve Politik Bilimler Dergisi, 1(2): 1-16.

Mathis, L.R. and Jackson, H.J. (2000). Human Resources Management (Ninth Edition), USA: South-Western College Publishing.

Neuman, W. L. (2017). Toplumsal Araştırma Yöntemleri, Ankara: Yayınodası.

Pabel, A., \& Pearce, P. L. (2016). “Tourists' responses to humor.” Annals of Tourism Research, 57, 190-205.

Pelit, E. (2015). Turizm İşletmelerinde İnsan Kaynakları Yönetimi, Ankara: Grafiker Yayınları.

Örücü, E. (2002). “Turizm İşletmelerinde Orta ve Üst Kademe Yöneticilerin İşgören Seçme ve Değerlendirme Sürecindeki Eğilimleri (Marmaris ve Çevresindeki Üç Yıldızlı İşletmeler Örneği)", Dokuz Eylül Üniversitesi İktisadi ve İdari Bilimler Fakültesi Dergisi, 17(2): 119-132.

Özgen, H. ve Yalçın, A. (2010). İnsan Kaynakları Yönetimi: Stratejik Bir Yaklaşım, Adana: Nobel Kitabevi.

Sabuncuoğlu, Z. (2016). İnsan Kaynakları Yönetimi, Bursa: Alfa Aktüel Yayıncılık.

Schum, C., Gatling, A. and Garlington, J. (2019). "All people are created equal? Racial discrimination and its impact on hospitality career satisfaction", International Journal of Hospitality Management, https://doi.org/10.1016/j.ijhm.2019.102407.

Skalpe, O. (2007). "The CEO gender pay gap in the tourism industry-Evidence from Norway", Tourism Management, 28 (2007) 845-853.

Temizkan, R. (2010). “İşgören Seçim Sürecinde İş Başvuru Formlarında Ayrımcllık: Konaklama İşletmelerinde Bir Uygulama", Yayınlanmamış Doktora Tezi, Ankara: Gazi Üniversitesi Eğitim Bilimleri Enstitüsü.

Thrane, C. (2008). "Earnings differentiation in the tourism industry: Gender, human capital, and sociodemographic effects", Tourism Management, 29 (2008) 514-52.

Tükeltürk, Ş., Perçin N. Ş. ve Güzel, B. (2014). Turizm İşletmelerinde Çalışan İlişkileri Yönetimi, Ankara: Detay Yayıncllık.

Ünlüönen, K., Tayfun, A. ve Kılıçlar, A. (2015). Turizm Ekonomisi, Ankara: Nobel Akademik Yayıncılık.

Viglia, G., \& Dolnicar, S. (2020). "A review of experiments in tourism and hospitality." Annals of Tourism Research, 80, 102858.

Yeşiltaş, M., Temizkan, R., Temizkan, S. P. ve Arslan, Ö. E. (2013). “Discrimination in Job Application Forms of Hospitality Industry", İşletme Araştırmaları Dergisi, 5(3): 18-36.

Yüksel, Ö. (2007). İnsan Kaynakları Yönetimi, Ankara: Gazi Kitabevi.

Zavattaro, S. M., \& Fay, D. L. (2019). "Brand USA: A natural quasi-experiment evaluating the success of a national marketing campaign." Tourism Management, 70, 42-48. 